\title{
The Effect of Training Through the Telegram Social Network on Osteoporosis-preventive Behaviour of Women
}

\author{
Telegram Sosyal Ağı Aracılığıyla Eğitimin Kadınların Osteoporoz Önleyici Davranışları \\ Üzerine Etkisi
}

(D) Zohreh Karimiankakolaki, (D) Maryam Khadibi*, (D) Seyed Hossein Mousavi**, (D) Fatemeh Heidari*** Department of Health, Shahrekord Branch, Islamic Azad University, Shahrekord, Iran *Department of Nursing, Shahrekord Branch, Islamic Azad University, Shahrekord, Iran

**Isfahan University of Medical Sciences, Isfahan, Iran

***Gerash University of Medical Science, Faculty of Nursing, Gerash, Iran

\section{Abstract}

Objective: Osteoporosis is the most prevalent metabolic bone disease, and women are the most important group at risk. The present study was conducted to determine the effect of training through the Telegram social network on the osteoporosis-preventive behaviour (OPB) of women.

Materials and Methods: This educational intervention study had a pre- and post-test design with a randomised control group. It was conducted on 60 women who referred to the health centres in Yazd suburbs. The women were randomly selected and assigned to the intervention and control groups. After filling out the questionnaires, the training messages package was sent to the intervention group via the Telegram group. One month later, the questionnaires were completed again, and the data were analysed using SPSS 18.0 and a paired and independent t-test.

Results: The mean age of the participants was 30.20 \pm 5.34 years. The paired t-test was used to compare the mean scores of OPB in both groups before and after the training. The results showed that the difference in the mean scores in the intervention group ( $p=0.00$ ) was significant compared with the control group, which was insignificant $(p=0.054)$. Independent t-test results revealed that the mean behaviour score after training in the intervention group was higher than in the control group $(p=0.00)$ and daily exercise behaviour had the highest mean increase.

Conclusion: Training through the virtual space of Telegram concerning osteoporosis is effective in preventing osteoporosis, and a daily exercise behavioural regimen has the highest increase compared with other preventive behaviours.

Keywords: Osteoporosis, preventive behaviour, training, Telegram

\section{Öz}

Amaç: Osteoporoz en sık görülen metabolik kemik hastalığıdır ve kadınlar risk altındaki en önemli gruptur. Bu çalışma, Telegram sosyal ağı aracılığıyla yapılan eğitimin osteoporoz önleyici davranış (OPB) kadınların üzerindeki etkisini belirlemek için yapıldı.

Gereç ve Yöntem: Yazd banliyölerinde sağlık merkezlerine başvuran 60 kadın üzerinde randomize kontrol grubu ön test ve son test türüne ait bu eğitimsel müdahale çalışması yapıımıştır. Kadınlar rastgele seçilmiş ve müdahale ve kontrol gruplarına atanmıştır. Anketleri doldurduktan sonra, eğitim mesajları paketi Telegram grubu üzerinden müdahale grubuna gönderildi. Bir ay sonra, anketler tekrar dolduruldu ve veriler SPSS 18.0 ve eşleştirilmiş ve bağımsı t-testi kullanılarak analiz edildi.

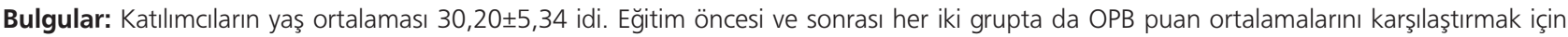
eşleştirilmiş t-test kullanıldı. Sonuçlar, müdahale grubundaki ortalama puanlardaki farkın $(p=0,00)$ kontrol grubuna göre anlamlı olmadığını $(p=0,054)$ göstermiştir. Bağımsız t-testi sonuçları, müdahale grubundaki antrenman sonrası ortalama davranış puanının kontrol grubundan $(p=0,00)$ daha yüksek olduğunu ve günlük egzersiz davranışının en yüksek ortalama artış gösterdiğini ortaya koydu.

Sonuç: Osteoporoz ile ilgili sanal Telegram alanı üzerinden eğitim almak, osteoporozun önlenmesinde etkilidir ve günlük egzersiz davranış alışkanlığı diğer koruyucu davranışlara göre en yüksek artışa sahiptir.

Anahtar kelimeler: Osteoporoz, önleyici davranış, eğitim, Telegram 


\section{Introduction}

Osteoporosis is the most prevalent metabolic bone disease. Today, it is known as a public health problem, whose importance increases with increase in the average age of the community, especially women (1). The World Health Organization (WHO) has considered it the fourth main human enemy and the most important reason for bone fracture in the world (2). According to statistics, the prevalence of osteoporosis in the thigh and spine of Iranian women is $18.9 \%$ (3). The Endocrinology and Metabolism Research Center of Tehran University of Medical Sciences has reported that $70 \%$ of women and $50 \%$ of men over 50 in Iran suffer from osteoporosis (4).

Gender (women 2 times more than men), skeletal size, race, inappropriate nutrition, consumption of substances such as cigarettes, caffeine, alcohol, and so on, decreased intake of calcium and vitamin $D$, low estrogen levels, premature menopause (before 49 years of age), and lack of physical mobility are the main risk factors for this disease. Moreover, family history of bone fractures, history of using corticosteroids for more than 6 months, hereditary diseases, Cushing's syndrome, hyperthyroidism and mal-absorption syndrome are the secondary causes of osteoporosis. Hence, having a healthy lifestyle, proper nutrition, enough calcium intake and exercise during the growth period are of particular importance in preventing osteoporosis in order ages, especially in women (5-7).

Osteoporosis is the silent epidemic of the present age, which usually has no symptoms, showing itself with bone fractures for the first time in case of lack of prevention and treatment (7). Primary prevention is usually for people under 50 and those who have still not been affected by osteoporosis. Since the greatest bone mass is formed in adolescents and young adults, prevention of this disease during this period is much more effective (8). Many investigations have introduced lifestyle changes, such as adequate intake of calcium and vitamin $D$, regular physical activity, exposure to sunlight, and avoidance of bad habits like use of cigarettes and hookahs, and following harsh weight loss diets effective in preventing osteoporosis (9-13).

A common cause of non-acceptance of osteoporosis-preventive behaviour (OPB) is the false belief that osteoporosis is not a serious disease (14). Babamohammadi et al. (15) examined the effect of training based on the health belief model (HBM) in empowering the volunteers to prevent osteoporosis through booklet education, and found if effective. Niazi et al. (16) tried a health-training program based on HBM in preventing osteoporosis by lecture methods. Edmonds et al. (17) (2012) conducted a study entitled "Knowledge and attitudes towards osteoporosis and calcium intake in students: based on the HBM". Hassan Al Seraty and Mohamed Ali (1) (2014) studied the effect of HBM-based intervention on prevention of osteoporosis among Saudi female students.

There is a huge burden of evidence showing that using information technology (IT) increases the efficiency of the learning process. Among the most important achievements of IT are the increase of learning quality of the learners, the ease of access to a large amount of information, fast and timely access to information at a very short time, and reduction in some educational costs (18). Although several studies have examined the advantages of e-learning compared with traditional education (19-21), to our knowledge, there are no studies concerning the usefulness of training through the Telegram social network in prevention of osteoporosis in Iran so far. The attractiveness of these training methods and higher tendency of women to join to and spend time in virtual networks encouraged us to make a change in the type of training and use the Telegram social network to send training messages on prevention of osteoporosis in order to determine the effect of training through this network on women's OPBs.

\section{Materials and Methods}

\section{The Study Sample}

This study was training intervention along pre-test - post-test with a randomized control group. According to a similar study by Khani Jeihouni et al. (6) to determine the sample size, confidence level of $0.95\left(z\left({ }_{1}-\frac{\alpha}{2}\right)=1.94\right)$, test power of $80 \% \quad\left(z \quad\left({ }_{1}-\beta\right)=0.84\right)$, and the standard deviation of self-efficacy score $S=2$, and $d=1.6$, the sample size of each group in the present study was estimated to be 27 subjects. Considering a total loss coefficient of $10 \%$, we included 30 people for each group, so overall, 60 people were included in the study. Cluster sampling was used for sampling, where two areas were randomly selected from the suburbs of Yazd city, and one health center was randomly selected from each region. Then, from among the clients of each health center, some were randomly assigned to participate in the study, who were randomly divided into the two groups of intervention and control based on the random numbers table.

\section{Measures}

The data were collected using a part of the questionnaire designed by Baghiani Moghadam et al. (22) including demographic questions, and OPBs (10 questions with Likert scale). This questionnaire was validated in Baghiani Moghadam et al. (22) study, by experts and health professionals for confirmation of the reliability, and its internal reliability was confirmed by calculating the Cronbach's alpha coefficient (behavior $\alpha=0.75$ ).

\section{The Study Design}

At first, an introduction session was held for all volunteers concerning the purpose of the study and the method of implementation of the project. After completing the questionnaires, training messages for promoting lifestyle of OPBs were sent to the participants in the intervention group through the Telegram social network, with the control group receiving no training. One month after the intervention, the participants in both groups completed the questionnaires again. At the end of the project, the training materials were provided to the control group too. 


\section{Educational Content}

The educational content included an introduction to osteoporosis, its predisposing factors, the prevalence and age of conflict with this disease, and the recommendations for OPB lifestyle with appropriate images. The preventive recommendations provided by WHO include diet, vitamin D supplementation, physical activity, exposure to sunlight, and smoking avoidance, which were presented along with some pictures about complications of osteoporosis. The training material was sent in 40 messages via Telegram. The messages were images and documents.

\section{Statistical Analysis}

After collecting the questionnaires, the data were analyzed using SPSS 18.0, frequency distribution tables, and paired and independent t-tests.

\section{Ethical Approval}

The Institutional Review Board at Shahid Sadoughi University of Medical Sciences approved the study (Ethical no: IR.SSU. REC.1395.111). The study participants were informed of the importance, purposes, and methods of the study. They were informed that participation in the study was voluntary and that they could refuse to participate or withdraw from the study at any time without being penalized or losing any benefits. The participants were reassured of confidentiality and signed the informed consent form.

\section{Results}

The mean age of women participating in the study was $30.20 \pm 5.34$ years. The majority of the subjects (65\%) had bachelors or higher degrees. The majority of them (56.7\%) were employed and the rest were housewives. Most of the subjects (50\%) had 1-2 deliveries. In terms of living conditions, 54 subjects $(90 \%)$ had moderate status.

The results of paired t-test to compare the mean scores of OPB in the intervention and control groups before and after training showed that the difference in the mean OPB score in the intervention group $(p=0.00)$ was significant but insignificant in the control group $(p=0.054)$. The independent t-test results revealed that the difference between the mean score of OPB before training was not significant between the two groups $(p=0.77)$, but after training, it was significant between the two groups $(p=0.00)$ (Table 1$)$.
Based on the distribution frequency and paired t-test results, the mean of OPBs including weight loss behavior, daily intake of dairy products, replacement of beverages with juice and doogh (a savory yogurt-based beverage), consumption of proper levels of fruits and vegetables, intake of calcium and vitamin D supplements, daily exercise for half an hour (three days a week), exposure to sunlight, and not smoking showed no significant changes in the intervention group before and after training $(p<0.05)$, while daily exercise had the greatest increase. Refusing to consume carbonated soft drinks and consuming fish and marine food did not change significantly ( $p>0.05)$. The details of other follow-up behaviors are given in Table 2 .

\section{Discussion}

As women are the most vulnerable group against osteoporosis, the purpose of this study was to specify the effect of training through the Telegram social network on OPBs in women.

The results showed that OPB mean scores among women before training did not have significant differences between the two groups. After OPB training, it increased in the intervention group significantly as compared to the control group. Consistent with these results, a study by Khani Jeihooni et al. (6) regarding the effect of OPB program showed that the mean scores of OPB in the intervention group increased compared to the control group. In this regard, Hassan Al Seraty and Mohamed Ali (1) examined the effect of training on the osteoporosis prevention and showed that the training program based on HBM had a meaningful role in improving awareness and OPBs and promoting health beliefs in the participants. Ghaffari et al. (23) reported that training program based on HBM was effective in promoting nutritional behaviors and OPBs. The study by Edmonds et al. (17) revealed that the training program on osteoporosis increased the awareness about risk factors and OPBs and reduced risky behaviors. Accordingly, one can state that training and information on osteoporosis can be effective in promoting OPBs.

The results concerning the details of preventive behaviors showed that daily exercise behavior ranged from 15 to 30 , and three days a week had the highest average. In line with these results, Khani Jeihooni et al. (6) suggested that women's education on osteoporosis is effective on improving their walking and diet. Consistent with this, Hassan Al Seraty and Mohamed Ali (1) found that training on prevention of

Table 1. The results of independent t-test and paired t-test for comparing the mean score of osteoporosis-preventive behaviour before end after training

\begin{tabular}{|l|l|l|l|l|l|}
\hline \multirow{2}{*}{$\begin{array}{l}\text { Group } \\
\text { OPB }\end{array}$} & Intervention & \multicolumn{2}{l|}{ Control } & $\begin{array}{l}\text { Inter-group } \\
\text { comparison } \\
\text { (independent t-test) }\end{array}$ \\
\cline { 2 - 6 } & Mean & SD & Mean & SD & 0.771 \\
\hline Before training & 35.46 & 5.45 & 35.90 & 6.40 & $0.0005^{*}$ \\
\hline After training & 39.33 & 4.15 & 35.10 & 6.21 & - \\
\hline Intra-group comparison (paired t-test) & $0.00 *^{*}$ & 0.054 & & \\
\hline *Significance level less than 0.05, SD: Standard deviation, OPB: Osteoporosis-preventive behaviour & & & \\
\hline
\end{tabular}


Table 2. The results of frequency of distribution of osteoporosis-preventive behaviour questions before and after training in the intervention group

\begin{tabular}{|l|l|l|l|}
\multirow{2}{*}{ OPB questions } & \multicolumn{2}{|c|}{ Mean \pm SD } \\
\cline { 2 - 4 } & Before training & After training & p \\
\hline 1. Reduction in overweight & $3.70 \pm 1.02$ & $4.14 \pm 0.60$ & $0.020^{*}$ \\
\hline 2. Daily intake of 2-3 units of dairy products & $3.93 \pm 0.90$ & $4.07 \pm 0.87$ & $0.031^{*}$ \\
\hline 3. Refusing to drink carbonated drinks & $4.20 \pm 0.76$ & $4.22 \pm 0.75$ & 0.574 \\
\hline 4. Replacing soft drinks with juice and doogh (a savory yogurt-based beverage) & $3.86 \pm 0.93$ & $4.37 \pm 0.62$ & $0.008^{*}$ \\
\hline 5. Consumption of proper levels of fruits and vegetables & $3.80 \pm 0.88$ & $4.03 \pm 0.51$ & $0.090^{*}$ \\
\hline 6. Consumption of fish and marine food & $3.23 \pm 0.97$ & $3.55 \pm 0.84$ & 0.161 \\
\hline 7. Taking calcium and vitamin D supplements & $3.26 \pm 1.20$ & $3.77 \pm 0.93$ & $0.016^{*}$ \\
\hline 8. Daily exercise for half an hour three days a week & $2.66 \pm 1.06$ & $3.33 \pm 0.87$ & $0.007^{*}$ \\
\hline 9. Exposure to sunlight 15-30 minutes per day & $2.66 \pm 1.04$ & $3.18 \pm 0.96$ & $0.003^{*}$ \\
\hline 10. No smoking and avoidance of secondhand smoke & $4.30 \pm 1.29$ & $4.62 \pm 0.79$ & $0.036^{*}$ \\
\hline *Significance level less than 0.05, OPB: Osteoporosis-preventive behaviour, SD: Standard deviation & & &
\end{tabular}

osteoporosis was an effective in increasing the participants' exercise and calcium intake behaviors. According to the study by Solimanian et al. (24), in designing interventions based on $\mathrm{HBM}$ to increase physical activity to prevent osteoporosis, in addition to modifying health beliefs, individual goals should also be considered too.

Our results showed that consumption of carbonated beverages and non-consumption of fish and marine food had no significant changes in the participant after the intervention. The study of Mahdavi et al. (25) indicated that considering cultural-social variables could improve the preventive nutritional measures of osteoporosis. The important point about this is that the misconception of using carbonated beverages by Iranian people with their food cannot be changed by education alone and needs acculturation. On the other hand, non-consumption of fish implies the necessity of making policies to empower people to buy fish and marine food and change their food basket.

Implementing a training program concerning OPB is essential for family members, especially for the breadwinner. However, training through cyberspace has managed to make significant changes, and several studies have examined the benefits of e-learning compared to traditional training (19-21). Nonetheless, there is now a dire need to consider educational programs for proper culture making through mass media. It is important that the future studies should take into account effective cultural and social factors in this regard.

\section{Study Limitations}

Despite interesting findings of this survey, it also has limitations such as the use of self-report questionnaires and the participation of only women in this study which may make the results not generalizable to another community.

\section{Conclusion}

The present research showed training through the Telegram social network concerning osteoporosis can be effective in increasing OPBs among the participants. The results further indicated that daily exercise behavior showed the highest increase compared to OPBs; however, consuming carbonated beverages and lack of consumption of fish and marine food were among the behaviors that did not change significantly, requiring culture making through mass media and change in socio-political factors in the society.

Acknowledgements: The authors would like to express their thanks and appreciation to the respected President of Health Faculty of the University, personnel of Yazd Health Centers, Islamic Azad University Shahrekord Branch and the women who participated in the study.

\section{Ethics}

Ethics Committee Approval: The Institutional Review Board at Shahid Sadoughi University of Medical Sciences approved the study (Ethical code: IR.SSU.REC.1395.111).

Informed Consent: The participants were reassured of confidentiality and signed the informed consent form.

Peer-review: Internally peer-reviewed.

\section{Authorship Contributions}

Surgical and Medical Practices: Z.K., Concept: Z.K., Design: F.H., Data Collection or Processing: M.K., Analysis or Interpretation: S.H.M., Literature Search: Z.K., Writing: F.H., Z.K.

Conflict of Interest: No conflict of interest was declared by the authors.

Financial Disclosure: This work was funded by School of Health, Shahid Sadoughi University of Medical Sciences, Yazd, Iran 


\section{References}

1. Hassan Al Seraty WH, Mohamed Ali WG. The impacts of health belief model based intervention for osteoporosis prevention among female students in Al Dawadmi Applied Medical Science, Shaqraa University, Saudi Arabia. J Biol Agric Health 2014;4:125-31.

2. Khorsandi M, Shamsi M, Jahani F. The survey of practice about prevention of osteoporosis based on health belief model in pregnant women in Arak City. J Rafsanjan Univ Med Sci 2013;12:35-46.

3. Farrokhseresht $R$, Solati $M$, Azizi M, Sarafraz $H$. Bone mineral density evaluation of post menopausal women who referred to Shahid Mohammadi hospital BMD center. Hormozgan Med J 2014;7:515-20.

4. Ebadi Fard Azar F, Solhi M, Zohoor A, Ali Hosseini M. The effect of health belief model on promoting preventive behaviors of osteoporosis among rural women of Malayer. J Qazvin Univ Med Sci 2012;16:58-64.

5. Ben-Natan M, Heyman N, Israel B, Joshua M. Evaluation of Osteoporosis Educational Program on Elders who Sustained an Osteoporotic Fracture. Int J 2014;7:602.

6. Khani Jeihooni A, Hidarnia A, Kaveh MH, Hajizadeh E. The effect of a prevention program based on health belief model on osteoporosis. J Res Health Sci 2015;15:47-53.

7. Shojaezadeh D, Sadeghi R, Tarrahi M J, Asadi M, Lashgarara B. Application of health belief model in prevention of osteoporosis in volunteers of Khorramabad City Health Centers, Iran. Health System Res 2012;5:183-92.

8. Naghashpour M, Shakerinejad G, Lourizadeh MR, Hajinajaf $S$, Jarvandi F. Nutrition education based on health belief model improves dietary calcium intake among female students of junior high schools. J Health Popul Nutr 2014;32:420-9.

9. Ghaffari M, Niazi S, Ramezankhani A, and Soori H. Knowledge of Female Students of Kalaleh city about Osteoporosis, calcium intake and physical activity: An Unacceptable Status. Iran J Nutr Sci Food Technol 2013;7:319-27.

10. Kelley G, Kelley K. Exercise and bone mineral density at the femoral neck in postmenopausal women:A meta-analysis of controlled clinical trials with individual patient data. Am J Obstet Gynecol 2006; 194:760-7.

11. Sarah L, Morgan M. Calcium and vitamin D in osteoporosis Rheum Dis Clin North Am 2001;27:101-30.

12. Borer K. Physical activity in the prevention and amelioration of osteoporosis in women : interaction of mechanical, hormonal and dietary factors. Sports Med 2005;35:779-830.

13. Lesan S, Mirheydari Z, Sotoudeh G, Khajeh Nasiri F, Koohdani F. Osteoporosis Related Food Habits and Behaviors: a Cross-Sectional Study among Female Teachers. Hayat 2011;16:86-94.
14. Ghafari M, Nasirzadeh M, Aligol M, Davoodi F, Nejatifar M, Kabiri S. Determinants of physical activity for prevention of osteoporosis among female students of Shahid Beheshti University of Medical Sciences: Application of health belief model. Pajoohandeh J 2014;19:244-50.

15. Babamohammadi $\mathrm{H}$, Asgari Majdabadi $\mathrm{H}$, Kahooei M. Application of health belief model in prevention of osteoporosis in volunteers. Daneshvar Med 2005;13:11-8.

16. Niazi S, Ghafari M, Noori A, Khodadoost M. Impacts of a health belief model-based education program about osteoporosis prevention on junior high school students' physical activity, Kalaleh, Iran, 2012. Jorjani Biomed J 2013;1:1-9.

17. Edmonds E, Turner LW, Usdan SL. Osteoporosis knowledge, beliefs, and calcium intake of college students: utilization of the health belief model. Open J Prev Med 2012;2:27-34.

18. Mehrdad N, Yaghoobi N, Aalaa M, Zolfaghari M. Evaluation of perceived satisfaction, usefulness and efficiency of virtual workshops from the perspective of faculty members and postgraduate students of Tehran University of Medical Sciences. J Med Educ Dev 2015;8:125-36.

19. Heber E, Ebert D D, Lehr D, Nobis S, Berking M, Riper H. Efficacy and cost-effectiveness of a web-based and mobile stress-management intervention for employees: design of a randomized controlled trial. BMC Public Health 2013;13:655.

20. Lim T, Fadzil M, and Mansor N. Mobile learning via SMS at Open University Malaysia: Equitable, effective, and sustainable. IRRODL 2011;12:122-37.

21. Rezai Rad M,Mohammadi Atargaleh R. Assessing the role of applying e-learning in the training and learning process from faculty members' Point of View at Payam Noor University, Mazandaran. MEDIA 2012:3:1-2

22. Baghiani Moghadam M, Khabiri F, Morovati Sharifabad M, Dehghan A, Falahzadeh $H$. Determination of social variables affected the health belief model in adopting preventive behaviors of osteoporosis. Tolooe Behdasht 2016;15:45-57.

23. Ghaffari M, Tavassoli E, Esmaillzadeh A, Hassanzadeh A. Effect of health belief model based intervention on promoting nutritional behaviors about osteoporosis prevention among students of female middle schools in Isfahan, Iran. J Edu Health Promot 2012;1:14.

24. Solimanian A, Niknami S, Hajizadeh I, Shojaeezadeh D, Tavousi M. Predictors of physical activity to prevent osteoporosis based on extended health belief model. Payesh (Health Monitor) 2014;13:313-20.

25. Mahdavi S, Karimzadeh Shirazi K, Malekzadeh J, Fararooei M. Preventing of osteoporosis: applying the health belief model. Adv Nurs Midwifery 2015;24:8530. 